\title{
Pengaruh Kesadaran, Kualitas Pelayanan, Pengetahuan Perpajakan, Dan Sanksi Perpajakan Pada Kepatuhan Wajib Pajak Reklame
}

\author{
Ni Putu Mirah Sri Devi Permatasari ${ }^{1}$ \\ Ni Ketut Lely Aryani $\mathbf{M}^{2}$ \\ ${ }^{1,2}$ Fakultas Ekonomi dan Bisnis Universitas Udayana (Unud), Bali, Indonesia \\ e-mail: mirahsridevi31@gmail.com
}

\begin{abstract}
ABSTRAK
Kesadaran masyarakat untuk mematuhi kewajiban perpajakan memegang peran penting dalam penerimaan pendapatan perpajakan. Penelitian ini dimaksudkan untuk mengetahui apakah kesadaran wajib pajak, kualitas pelayanan, pengetahuan perpajakan, dan persepsi tentang sanksi perpajakan berpengaruh pada kepatuhan wajib pajak reklame di Badan Pendapatan Daerah Kabupaten Badung. Metode penentuan sampel dalam penelitian ini menggunakan teknik sampling insidental dengan jumlah responden sebanyak 54 wajib pajak. Teknik analisis data yang digunakan adalah analisis regresi linier berganda. Pengaruh kesadaran wajib pajak, kualitas pelayanan, pengetahuan perpajakan dan presepsi tentang sanksi perpajakan terhadap kepatuhan wajib pajak reklame sebesar $98,3 \%$. Pengaruh kesadaran wajib pajak terhadap kepatuhan wajib pajak reklame sebesar $1 \%$. Pengaruh kualitas pelayanan terhadap kepatuhan wajib pajak reklame sebesar 2,2\% Pengetahuan perpajakan terhadap kepatuhan wajib pajak reklame sebesar $4,8 \%$. Pengaruh presepsi wajib pajak tentang sanksi perpajakan terhadap kepatuhan wajib pajak reklame sebesar $92 \%$
\end{abstract}

Kata kunci : Kepatuhan wajib pajak, kesadaran wajib pajak, kualitas pelayanan, pengetahuan perpajakan, persepsi wajib pajak tentang sanksi perpajakan.

\begin{abstract}
Public awareness to comply with taxation obligations play an important role in tax revenue revenue. This study is intended to determine whether taxpayer awareness, service quality, tax knowledge, and perceptions of tax sanctions have an effect on advertisement taxpayer compliance in the Regional Revenue Board of Badung Regency.. The method of determining the sample in this study using incidental sampling techniques with the number of respondents as many as 54 taxpayers. The data analysis technique used is multiple linear regression analysis. The effect of taxpayer awareness, service quality, tax knowledge and perceptions about tax sanctions on advertisement tax compulsory compliance of $98.3 \%$. The effect of taxpayer awareness on advertisement taxpayer compliance is $1 \%$. The effect of service quality on advertisement taxpayer compliance is $2.2 \%$. Knowledge of taxation on advertisement taxpayer compliance is $4.8 \%$. The influence of taxpayer perceptions about tax sanctions on advertisement taxpayer compliance is $92 \%$.

Keywords: Taxpayer Compliance, Taxpayer Awareness, Service Quality, Tax Knowledge, Taxpayer Perception About Tax Sanctions.
\end{abstract}

\section{PENDAHULUAN}

Kabupaten Badung mengalami pertumbuhan yang sangat pesat terutama pada sektor usaha dan industri- industri. Salah satu pajak daerah yang memiliki potensi 
Ni Putu Mirah Sri Devi Permatasari dan Ni Ketut Lely Aryani M. Pengaruh ...

untuk digali di Kabupaten Badung adalah pajak reklame. Banyaknya jumlah usaha yang ada di Kabupaten Badung seharusnya dapat membantu meningkatkan pendapatan daerah khususnya pajak reklame.

Reklame yang terpasang di wilayah Kabupaten Badung berpotensi untuk mendukung Pemerintah Kabupaten Badung dalam meningkatkan PAD melalui pajak reklame, seperti yang tercantum dalam Peraturan Daerah Kabupaten Badung Nomor 18 Tahun 2011 Tentang Pajak Reklame yang menyebutkan bahwa pajak reklame merupakan salah satu sumber pendapatan daerah yang penting guna membiayai penyelenggaraan pemerintah daerah berdasarkan prinsip demokrasi, pemerataan dan keadilan, peran serta masyarakat dan akuntabilitas dengan memerhatikan potensi daerah.

Kenyataannya realisasi penerimaan pajak reklame yang diperoleh oleh pemerintah daerah belum memperoleh hasil yang maksimal. Hal itu bisa dilihat dari realisasi penerimaan pajak reklame tahun 2013-2017 dalam Tabel. 1 berikut.

Tabel 1 menunjukkan bahwa realisasi penerimaan pajak reklame Kabupaten Badung mengalami penurunan setiap tahunnya dan sedikit mengalami peningkatan di akhir tahun 2017, sedangkan target yang ditetapkan pemerintah selalu mengalami peningkatan. Jumlah pendapatan terendah secara persentase terjadi pada tahun 2015 yaitu hanya sebesar 0,21 persen. 
Tabel 1.

Rekapitulasi Target dan Realisasi Penerimaan Pendapatan Pajak Reklame

Kabupaten Badung Tahun 2013 - 2017

\begin{tabular}{cccc}
\hline Tahun & $\begin{array}{c}\text { Target Penerimaan Pajak } \\
(\mathrm{Rp})\end{array}$ & $\begin{array}{c}\text { Realisasi Penerimaan Pajak } \\
(\mathrm{Rp})\end{array}$ & $\begin{array}{c}\text { Persentase } \\
\text { Penerimaan } \\
\text { Pajak } \\
(\%)\end{array}$ \\
\hline 2013 & 7.500 .000 .000 & & 0,88 \\
2014 & 8.500 .000 .000 & 6.606 .523 .205 & 0,31 \\
2015 & 13.000 .000 .000 & 2.717 .873 .354 & 0,21 \\
2016 & 14.000 .000 .000 & 2.855 .069 .804 & 0,23 \\
2017 & 14.000 .000 .000 & 3.359 .451 .173 & 0,36
\end{tabular}

Sumber: Badan Pendapatan Daerah Kabupaten Badung, 2018

Target pendapatan daerah dari sekor pajak reklame Kabupaten Badung sampai saat ini baru mencapi Rp 3 miliar dari target Rp 14 miliar hingga akhir tahun 2016. Pencapaian yang tidak maksimal ini lantaran banyaknya papan reklame yang tak memiliki izin atau belum terdaftar. Pemerintah tidak dapat memenuhi target pendapatan reklame, karena tidak bisa memungut pajak dari papan reklame yang tidak memiliki izin.

Rendahnya kontribusi penerimaan pajak reklame akan terus terjadi apabila tingkat kepatuhan wajib pajak dalam memenuhi kepatuhan wajib pajaknya masih rendah, hal ini dapat dilihat hingga akhir tahun 2017 pendapatan daerah dari sektor pajak reklame Kabupaten Badung hanya mencapai Rp 5 miliar dari target Rp 14 miliar yang telah ditetapkan.

Tingkat kepatuhan wajib pajak dalam mendaftarkan reklamenya dapat dilihat dari jumlah wajib pajak yang terdaftar di Badan Pendapatan Daerah Kabupaten Badung. Tabel 1.2 memerlihatkan jumlah wajib pajak reklame dari tahun $2013-2017$. 
Tabel 2.

Jumlah Potensi dan Realisasi Wajib Pajak Reklame Kabupaten Badung Tahun 2013-2017

\begin{tabular}{cccc}
\hline Tahun & Jumlah wajib pajak potensi & $\begin{array}{c}\text { Jumlah wajib pajak } \\
\text { realisasi }\end{array}$ & $\begin{array}{c}\text { Persentase } \\
\text { jumlah wajib } \\
\text { pajak } \\
(\%)\end{array}$ \\
\hline 2013 & & 0,43 \\
2014 & 1.005 & 438 & 0,16 \\
2015 & 1.072 & 172 & 0,12 \\
2016 & 1.062 & 130 & 0,13 \\
2017 & 1.238 & 165 & 0,08 \\
\hline
\end{tabular}

Sumber :Data diolah, 2018

Tabel 2 menunjukkan bahwa terjadi peningkatan pada jumlah wajib pajak potensi setiap tahunnya. Namun peningkatan jumlah potensi wajib pajak berbanding terbalik dengan jumlah wajib pajak realisasi yang mengalami penurunan.

Penurunan jumlah wajib pajak yang terjadi setiap tahunnya mengindikasikan bahwa kepatuhan wajib pajak dalam memenuhi kewajibannya dalam hal mendaftarkan reklame yang didirikan masih harus ditingkatkan, kepatuhan wajib pajak reklame untuk memenuhi kewajiban pajaknya sangat menentukan peningkatan peran serta pajak reklame dalam membiayai penyelenggaraan pemerintah daerah dan pembangunan daerah.

Masalah kepatuhan pajak merupakan masalah klasik yang dihadapi hampir di semua negara yang menerapkan sistem perpajakan. Kepatuhan pajak yang tidak meningkat akan mengancam upaya pemerintah untuk meningkatkan kesejahteraan masyarakat (Gerald \& Leung, 2009). Mencapai tingkat kepatuhan pajak dan memertahankan tingkat kepatuhan saat ini merupakan isu yang menjadi perhatian 
para pembuat kebijakan baik di negara maju maupun negara berkembang (Razak \& Adafula, 2013)

Tingkat kepatuhan wajib pajak dalam mematuhi kewajiban perpajakannya dipengaruhi oleh beberapa faktor, salah satunya adalah kesadaran wajib pajak. Kesadaran wajib pajak menjadi hal yang penting karena didalam melaporkan dan membayar kewajiban perpajakan di Indonesia menggunakan penerapan self assessment system. Penerapan yang dimana Wajib Pajak diberi kepercayaan untuk mendaftar, menghitung, memperhitungkan, membayar dan melaporkan sendiri kewajiaban perpajakannya itu menjadikan kesadaran Wajib Pajak sebagai kunci keberhasilan pemungutan pajak (Mahfud, 2017).

Ketika masyarakat memiliki kesadaran maka membayar pajak akan dilakukan secara sukarela bukan keterpaksaan, sehingga membantu pemerintah daerah dalam memaksimalkan pendapatan pajak yang dapat digunakan sepenuhnya dalam proses pembangunan untuk meningkatkan kesejahteraan masyarakat (Darmayanti \& Rahayu, 2017)Kesadaran masyarakat yang tinggi akan mendorong semakin banyak masyarakat memenuhi kewajibannya untuk mendaftarkan diri sebagai wajib pajak, melaporkan dan membayar pajaknya dengan benar sebagai wujud tanggung jawab berbangsa dan bernegara (James \& Nobes, 1997).

Tinggi rendahnya kepatuhan wajib pajak dalam mematuhi kewajiban perpajakannya juga dipengaruhi oleh kualitas pelayanan. Memberikan pelayanan dengan baik terhadap wajib pajak akan membuat wajib pajak senantiasa memenuhi segala kewajiban dan haknya, karena wajib pajak akan senang dan 
merasa dimudahkan dan terbantu dalam menyelesaikan kewajiban- kewajibannya di bidang perpajakan. Peningkatan dari segi kualitas dan kuantitas suatu pelayanan diharapkan mampu meningkatkan kepuasan wajib pajak sebagai seorang pelanggan sehingga meningkatkan dalam bidang perpajakan.

Selain kualitas pelayanan, faktor yang memengaruhi kepatuhan wajib pajak adalah pengetahuan wajib pajak. Faktor pengetahuan sangat penting dalam membantu wajib pajak melaksanakan kewajibannya khususnya pengetahuan dasar tentang perpajakan (Noormala, 2008). Pengetahuan perpajakan adalah informasi yang dapat digunakan wajib pajak sebagai dasar untuk bertindak dan mengambil keputusan sehubungan dengan pelaksanaan hak dan kewajiban dibidang perpajakannya, atau dengan kata lain, pengetahuan perpajakan merupakan suatu sikap pola pikir, pemahaman atau penilaian seseorang terhadap pajak yang akan memengaruhi sikapnya dalam memenuhi kewajiban perpajakannya (Lisnawati, 2012). Pengetahuan pajak yang rendah dapat mengakibatkan ketidak percayaan dalam sikap negatif terhadap pajak, sedangkan pengetahuan pajak yang baik berkorelasi dengan sikap positif terhadap pajak (Niemirowski et al., 2002). Palil (2005)mengemukakan bahwa pengetahuan Wajib Pajak tentang pajak yang baik akan dapat memperkecil adanya tax evation.

Persepsi tentang sanksi perpajakan juga menjadi salah satu faktor yang memengaruhi tinggi rendahnya tingkat kepatuhan wajib pajak. Persepsi wajib pajak mengenai sanksi perpajakan adalah faktor penting dalam menentukan kepatuhan wajib pajak dalam membayar pajaknya (Fisher, Wartick, \& Mark, 1992). Pelanggaran peraturan perpajakan akan dapat ditekan apabila terdapat 
sanksi perpajakan yang mengaturnya. Tiraada (2013)mengatakan bahwa sanksi pajak merupakan faktor yang memberikan pengaruh terbesar terhadap kepatuhan wajib pajak dan ini berhubungan dengan sanksi yang tidak ringan yang dapat diterima oleh wajib pajak ketika terdapat suatu keterlambatan, pelanggaran administratif atau pidana terhadap penetapan pajak atas wajib pajak tersebut. Adanya pandangan wajib pajak tentang banyaknya kerugian yang dapat ditimbulkan akibat tidak memenuhi kewajiban perpajaknnya akan mendorong wajib pajak untuk patuh pada kewajibannya, dengan kata lain sanksi perpajakn juga dapat menjadi alat pencegah timbulnya ketidakpatuhan Wajib Pajak.

Kesadaran wajib pajak adalah suatu kondisi dimana wajib pajak mengetahui, memahami dan melaksanakan ketentuan perpajakan dengan benar dan sukarela. Kesadaran wajib pajak atas fungsi perpajakan sebagai pembiayaan negara sangat diperlukan untuk meningkatkan kepatuhan wajib pajak (Jatmiko, 2006)

Teori perilaku yang direncanakan (Theory of Planned Behavior) menjelaskan bahwa perilaku yang ditimbulkan oleh individu muncul karena adanya niat untuk berperilaku. Sikap yang mendorong perilaku merupakan derajat dimana seseorang memiliki sikap positif atau negatif terhadap perilaku yang akan ditimbulkan. Theory of Planned Behavior relevan untuk menjelaskan perilaku wajib pajak dan adanya kesadaran wajib pajak dalam mematuhi kewajiban perpajakannya sehingga dapat meningkatkan kepatuhan wajib pajak. Wajib pajak akan memiliki keyakinan mengenai pentingnya membayar pajak untuk menyelenggarakan pembangunan negara jika mereka sadar akan pentingnya 
membayar pajak. Dengan timbulnya kesadaran yang tinggi didalam diri wajib pajak diharapkan akan berdampak kepada semakin tingginya kepatuhan wajib pajak dalam memenuhi kewajibannya membayar pajak.

Penelitian yang dilakukan oleh Munari (2005)menyatakan bahwa kesadaran wajib pajak berpengaruh terhadap kepatuhan wajib pajak. Jatmiko (2006)mengemukakan bahwa kesadaran perpajakan masyarakat yang rendah seringkali menjadi salah satu sebab banyaknya potensi pajak yang tidak dapat dijaring. Dalam penelitian Jaya \& Jati (2016)menyatakan bahwa kesadaran wajib pajak berpengaruh signifikan terhadap kepatuhan wajib pajak. Berdasarkan hal tersebut maka dirumuskan hipotesis sebagai berikut.

$\mathrm{H}_{1}$ : Kesadaran wajib pajak berpengaruh positif terhadap kepatuhan wajib pajak.

Kepatuhan Wajib Pajak dalam memenuhi kewajiban membayar pajak tergantung pada bagaimana petugas pajak memberikan mutu pelayanan yang terbaik kepada wajib pajak (Jatmiko, 2006). Fiskus diharapkan memiliki kompetensi dalam arti memiliki keahlian, pengetahuan, dan pengalaman dalam hal kebijakan perpajakan, administrasi pajak dan perundang-undangan perpajakan. Selain itu fiskus juga harus memiliki motivasi yang tinggi sebagai pelayan publik (Wirawan \& Burton, 2013:212).

Pengetahuan perpajakan dalam teori atribusi, merupakan salah satu faktor eksternal yang dapat mempengaruhi prilaku kepatuhan wajib pajak dalam membayar pajak. Teori atribusi menjelaskan mengenai proses bagaimana kita menentukan penyebab dan motif mengenai perilaku seseorang. Pelayanan yang terjadi melalui interaksi antara wajib pajak dengan karyawan atau petugas pajak 
saat wajib pajak membayar pajak akan membentuk suatu kesan. Wajib pajak akan menganggap pelayanan itu berkualitas saat petugas pajak memberikan kesan yang baik seperti ramah, bersikap hormat, menjaga sopan santun, serta mempunyai pengetahuan untuk memberi informasi yang jelas terhadap wajib pajak. Apabila wajib pajak sudah merasa puas dengan pelayanan yang diberikan maka akan berdampak pada meningkatnya kepatuhan wajib pajak.

Menurut Marziana, Norkhazimah, \& Sakarnor (2010) dalam penelitiannya menyatakan bahwa faktor yang mempengaruhi kepatuhan Wajib Pajak adalah kepuasan layanan dan pengetahuan perpajakan. Semakin tinggi masyarakat mengetahui informasi tentang pengetahuan pajak terkait belanja publik, maka kepatuhan wajib pajak juga akan semakin lebih tinggi. Hal ini juga didukung oleh penelitian Kusuma \& Supadmi (2016)yang menyatakan bahwa kualitas pelayanan berpengaruh positif terhadap kepatuhan wajib pajak. Berdasarkan uraian tersebut maka dirumuskan hipotesis sebagai berikut.

$\mathrm{H}_{2}$ : Kualitas pelayanan berpengaruh positif terhadap kepatuhan wajib pajak.

Pengetahuan perpajakan dalam teori atribusi, merupakan salah satu faktor eksternal yang dapat mempengaruhi prilaku kepatuhan wajib pajak dalam membayar pajak. Sedangkan dalam teori pengambilan keputusan bertujuan untuk mengetahui manfaat dari pengetahuan perpajakan. Pengetahuan pajak merupakan informasi pajak yang dapat digunakan Wajib Pajak sebagai dasar untuk bertindak, mengambil keputusan dan untuk menempuh arah atau strategi tertentu sehubungan dengan pelaksanaan hak dan kewajibannya dibidang perpajakan. Pada penelitian yang dilakukan oleh Nugroho (2012) menyatakan semakin tinggi 
pengetahuan dan pemahaman Wajib Pajak, maka Wajib Pajak dapat menentukan perilakunya dengan lebih baik dan sesuai dengan ketentuan perpajakan. Namun jika Wajib Pajak tidak memiliki pengetahuan mengenai peraturan dan proses perpajakan, maka Wajib Pajak tidak dapat menentukan prilakunya dengan tepat.

Pada penelitian yang dilakukan oleh Sucandra \& Supadmi (2016)yaitu analisis pengaruh kualitas pelayanan, pemeriksaan pajak, pengetahuan perpajakan dan sanksi perpajakan pada kepatuhan wajib pajak restoran, diperoleh hasil yang menunjukkan variabel pengetahuan perpajakan memiliki pengaruh positif dan signifikan terhadap kepatuhan wajib pajak restoran. Budhiartama \& Jati (2016)menyatakan dalam penelitiannya bahwa pengetahuan perpajakan memiliki pengaruh positif dan signifikan terhadap kepatuhan Wajib Pajak. Berdasarkan uraian tersebut maka dirumuskan hipotesis sebagai berikut.

$\mathrm{H}_{3}$ : Pengetahuan perpajakan berpengaruh positif pada kepatuhan wajib pajak

Berdasarkan Theory of Planned Behavior persepsi wajib pajak terkait dengan control beliefs yaitu keyakinan tentang keberadaan hal-hal yang mendukung atau menghambat perilaku dan persepsi tentang seberapa kuat hal-hal tersebut mempengaruhi perilakunya. Penelitian ini menggunakan indikator persepsi tentang sanksi perpajakan sebagai kontrol perilaku wajib pajak untuk taat pajak.

Berdasarkan penelitian yang dilakukan oleh Mohammad Zain (2008:34) menyatakan bahwa sesungguhnya tidak diperlukan suatu tindakan apabila dengan rasa takut dan ancaman hukuman (sanksi dan pidana) saja wajib pajak sudah akan mematuhi kewajiban perpajakannya. Perasaan takut tersebut merupakan alat 
pencegah yang andal untuk mengurangi penyelundupan pajak atau kelalaian pajak. Jika hal ini sudah berkembang dikalangan para wajib pajak maka akan berdampak pada kepatuhan dan kesadaran untuk memenuhi kewajiban perpajakannya.

Pandangan Wajib Pajak tentang banyaknya kerugian yang akan dialaminya apabila melanggar kewajiban membayar pajak akan mendorong wajib pajak untuk patuh pada kewajiban perpajaknnya (Jatmiko, 2006). Hasil penelitian Sucandra \& Supadmi (2016) menyatakan bahwa sanksi perpajakan berpengaruh positif dan signifikan terhadap kepatuhan wajib pajak. Begitu juga dengan penelitian yang dilakukan oleh Dewi \& Merkusiwati (2018)yang menyatakan bahwa sanksi perpajakan berpengaruh positif pada kepatuhan wajib pajak. Berdasarkan uraian tersebut maka dirumuskan hipotesis sebagai berikut.

$\mathrm{H}_{4}$ : Persepsi tetang sanksi perpajakan berpengaruh positif terhadap kepatuhan wajib pajak.

\section{METODE PENELITIAN}

Penelitian ini menggunakan pendekatan kuantitatif berbentuk asosiatif, penelitian ini dilakukan untuk mengetahui pengaruh kesadaran wajib pajak, kualitas pelayanan, pengetahuan perpajakan, dan persepsi tentang sanksi perpajakan pada kepatuhan wajib pajak reklame di Badan Pendapatan Daerah Kabupaten Badung.

Penelitian ini dilakukan di Badan Pendapatan Daerah Kabupaten Badung yang beralamat di Jalan Raya Sempidi-Mengwi, Badung, dan kantor-kantor Wajib Pajak Reklame Kabupaten Badung untuk memperoleh data primer. Badan 
Ni Putu Mirah Sri Devi Permatasari dan Ni Ketut Lely Aryani M. Pengaruh ...

Pendapatan Daerah Kabupaten Badung dipilih sebagai lokasi penelitian dengan pertimbangan terdapat fenomena pajak reklame yang tidak mencapai target.

Objek dalam penelitian ini adalah kepatuhan wajib pajak dalam membayar Pajak Reklame di Badan Pendapatan Daerah Kabupaten Badung. Dalam penelitian ini yang menjadi variabel bebas adalah 1) Kesadaran Wajib Pajak $\left(\mathrm{X}_{1}\right)$ 2) Kualitas Pelayanan $\left(X_{2}\right)$ 3) Pengetahuan Perpajakan $\left(X_{3}\right)$ 4) Persepsi Wajib Pajak Tentang Sanksi Perpajakan $\left(\mathrm{X}_{4}\right)$. Dalam penelitian ini yang menjadi variabel terikat yaitu (Y) Kepatuhan Wajib Pajak Reklame dalam membayar pajak reklame.

Populasi dalam penelitian ini adalah wajib pajak reklame yang terdaftar pada Badan Pendapatan Daerah Kabupaten Badung.Metode penentuan sampel yang digunakan dalam penelitian ini adalah metode sampling insidental. Responden yang digunakan dalam penelitian ini adalah sebanyak 54 wajib pajak reklame yang terdaftar di Badan Pendapatan Daerah Kabupaten Badung.Teknik pengumpulan data yang digunakan dalam penelitian ini adalah kuesioner dan partisipasi pasif

\section{HASIL DAN PEMBAHASAN}

Sebagian besar responden penelitian ini adalah laki-laki yaitu sebanyak 30 orang (56 persen) dan 24 orang responden ( 24 persen) perempuan. Responden dengan jumlah tertinggi yaitu golongan umur 21-31 tahun sebanyak 20 orang responden (37 persen). Responden dengan tingkat pendidikan S1 merupakan responden dengan jumlah tertinggi yaitu sebanyak 27 responden (50 persen). 
Berdasarkan Tabel 3 di atas dapat diketahui bahwa banyaknya kuesioner yang diolah adalah 54 kuesioner untuk masing-masing variabel. Variabel kesadaran wajib pajak (X1) mempunyai nilai minimum sebesar 11,00 dan nilai maksimum sebesar 16,00. Nilai rata-rata sebesar 13,778 dengan standar deviasi 1,449. Standar deviasi yang tidak cukup besar $(10,5 \%$ dari mean $)$ menunjukkan adanya variasi yang tidak cukup besar dari nilai terendah dan nilai tertinggi untuk variabel X1.

Tabel 3. Hasil Statistik Deskriptif

\begin{tabular}{|c|c|c|c|c|c|}
\hline Variabel & $\mathrm{N}$ & Min & $\operatorname{Max}$ & Mean & $\begin{array}{c}\text { Std. } \\
\text { Deviasi }\end{array}$ \\
\hline Kesadaran Wajib Pajak & 54 & 11.00 & 16.00 & 13.778 & 1.449 \\
\hline Kualitas Pelayanan & 54 & 45.00 & 63.00 & 56.462 & 4.372 \\
\hline Pengetahuan Perpajakan & 54 & 8.00 & 12.00 & 10.055 & 1.419 \\
\hline $\begin{array}{l}\text { PersepsiTentang Sanksi } \\
\text { Perpajakan }\end{array}$ & 54 & 8.00 & 12.00 & 10.204 & 1.337 \\
\hline $\begin{array}{l}\text { Kepatuhan Wajib Pajak } \\
\text { Reklame }\end{array}$ & 54 & 11.00 & 16.00 & 13.685 & 1.778 \\
\hline
\end{tabular}

Variabel kualitas pelayanan (X2) mempunyai nilai minimum 45,00 dan nilai maksimum sebesar 63,00 . Nilai rata-rata sebesar 56,462 dengan standar deviasi 4,372. Standar deviasi yang tidak cukup besar (7,7\% dari mean) menunjukkan adanya variasi yang tidak cukup besar dari nilai terendah dan nilai tertinggi untuk variabel X2.

Variabel pengetahuan perpajakan (X3) mempunyai nilai minimum 8,00 dan nilai maksimum sebesar 12,00. Nilai rata-rata sebesar 10,055 dengan standar deviasi sebesar 1,419. Standar deviasi yang tidak cukup besar (13,9\% dari mean) menunjukkan adanya variasi yang tidak cukup besar dari nilai terendah dan nilai tertinggi untuk variabel X3 
Ni Putu Mirah Sri Devi Permatasari dan Ni Ketut Lely Aryani M. Pengaruh ...

Variabel persepsi tentang sanksi perpajakan (X4) mempunyai nilai minimum sebesar 8,00 dan nilai maksimum sebesar 12,00 . Nilai rata-rata sebesar 10,204 dan nilai standar deviasi sebesar 1,337. Nilai standar deviasi yang tidak cukup besar $(13,1 \%$ dari mean $)$ menunjukkan adanya variasi yang tidak cukup besar dari nilai terendah dan nilai tertinggi untuk variabel X4.

Variabel kepatuhan wajib pajak reklame (Y) mempunyai nilai minimum sebesar 11,00 dan nilai maksimum sebesar 16,00. Nilai rata-rata sebesar 13,685 dengan standar deviasi 1,778 . Standar deviasi yang tidak cukup besar $(0,12 \%$ dari mean) menunjukkan adanya variasi yang tidak cukup besar dari nilai terendah dan nilai tertinggi untuk variabel $\mathrm{Y}$.

Variabel kesadaran wajib pajak memiliki pearson correllation dari 0,496 $0,858(>0,279)$, yang mengandung arti bahwa pernyataan tersebut valid. Variabel kualitas pelayanan memiliki pearson correllation dari $0,552-0,569(>0,279)$, yang mengandung arti bahwa pernyataan tersebut valid. Variabel pengetahuan perpajakan memiliki pearson correllation dari $0,852-0,637(>0,279)$, yang mengandung arti bahwa pernyataan tersebut valid. Variabel persepsi wajib pajak tentang sanksi perpajakan memiliki pearson correllation dari $0,831-0,853$ $(>0,279)$, yang mengandung arti bahwa pernyataan tersebut valid serta variabel kepatuhan wajib pajak reklame memiliki pearson correllation dari 0,908-0,914 $(>0,279)$, yang mengandung arti bahwa pernyataan tersebut valid.

Tabel 4.

Hasil Uji Reliabilitas

No. Variabel Penelitian $\quad$ Cronbach'c Alpha $\quad$ Keterangan




\begin{tabular}{llll}
\hline 1. & Kesadaran Wajib Pajak & 0,617 & Reliabel \\
2. & Kualitas Pelayanan & 0,759 & Reliabel \\
3. & Pengetahuan Perpajakan & 0,627 & Reliabel \\
4. & Persepsi Tentang Sanksi Perpajakan & 0,640 & Reliabel \\
5. & Kepatuhan Wajib Pajak Reklame & 0,794 & Reliabel
\end{tabular}

Sumber : Data diolah, 2019

Berdasarkan Tabel 4 terlihat bahwa seluruh instrumen penelitian yaitu variabel kesadaran wajib pajak, kualitas pelayanan, pengetahuan perpajakan, persepsi tentang sanksi perpajakan, dan kepatuhan wajib pajak reklame memiliki Cronbach'c Alpha lebih besar dari 0,60 sehingga dapat dinyatakan bahwa pernyataan pada kuesioner tersebut reliabel.

Hasil uji normalitas menunjukkan bahwa koefisien Asymp.Sig (2-tailed) adalah 0,200 yang lebih besar dari 0,05. Hal ini berarti model regresi berdistribusi normal.

Tabel 5. Hasil Uji Multikolinearitas

\begin{tabular}{lcc}
\hline \multicolumn{1}{c}{ Variabel Penelitian } & Tolerance & VIF \\
\hline Kesadaran Wajib Pajak & 0,240 & 4,170 \\
Kualitas Pelayanan & 0,727 & 1,375 \\
Pengetahuan Perpajakan & 0,107 & 9,334 \\
Persepsi Tentang Sanksi Perpajakan & 0,112 & 8,891 \\
\hline
\end{tabular}
Sumber : Data diolah, 2019

Berdasarkan Tabel 5 dapat diketahui bahwa nilai tolerance masing-masiing variabel lebih besar dari 10\% atau 0,1 dan nilai VIF masing-masing variabel lebih kecil dari 10. Hasil uji multikolinearitas tersebut menyimpulkan bahwa model regresi bebas dari masalah multikolinearitas dan dapat digunakan dalam penelitian.

Tabel 6.

Hasil Uji Heteroskedastisitas

\begin{tabular}{lcc}
\hline \multicolumn{1}{c}{ Variabel Penelitian } & Sig. & Keterangan \\
\hline Kesadaran Wajib Pajak & 0,435 & Bebas Heteroskedastisitas \\
Kualitas Pelayanan & 0,266 & Bebas Heteroskedastisitas \\
Pengetahuan Perpajakan & 0,567 & Bebas Heteroskedastisitas \\
Persepsi Wajib Pajak Tentang Sanksi & 0,409 & Bebas Heteroskedastisitas \\
\hline
\end{tabular}


Ni Putu Mirah Sri Devi Permatasari dan Ni Ketut Lely Aryani M. Pengaruh ...

Perpajakan

Sumber : Data diolah, 2019

Berdasarkan Tabel 6 dapat dilihat bahwa nilai sig. masing-masing variabel berada di atas 0,05. Hasil uji heteroskedastisitas tersebut menyimpulkan bahwa model regresi yang digunakan bebas heteroskedastisitas.

Berdasarkan Tabel 7 dapat disusun persamaan regresi sebagai berikut.

$$
\hat{Y}=0,933+0,094 X 1+0,067 X 2+0,165 X 3+0,782 X 4
$$

Tabel 7.

Hasil Regresi Linear Berganda

\begin{tabular}{|c|c|c|c|c|c|c|}
\hline \multirow[t]{2}{*}{ Variabel } & \multicolumn{2}{|c|}{$\begin{array}{l}\text { Unstandardized } \\
\text { Coefficients }\end{array}$} & \multirow{2}{*}{$\begin{array}{c}\text { Standardized } \\
\text { Coefficients } \\
\text { Beta }\end{array}$} & \multirow[t]{2}{*}{$\mathrm{t}$} & \multirow[t]{2}{*}{ Sig. } & \multirow[t]{2}{*}{ Importance } \\
\hline & $\mathrm{B}$ & $\begin{array}{l}\text { Std. } \\
\text { Error }\end{array}$ & & & & \\
\hline (Constant) & 0,933 & 0,446 & & 2,091 & 0,042 & \\
\hline $\begin{array}{l}\text { Kesadaran Wajib Pajak } \\
\text { (X1) }\end{array}$ & 0,155 & 0,046 & 0,094 & 2,505 & 0,016 & 0,010 \\
\hline Kualitas Pelayanan (X2) & 0,027 & 0,009 & 0,067 & 3,101 & 0,003 & 0,022 \\
\hline $\begin{array}{l}\text { Pengetahuan Perpajakan } \\
\text { (X3) }\end{array}$ & 0,207 & 0,070 & 0,165 & 2,941 & 0,005 & 0,048 \\
\hline $\begin{array}{l}\text { Persepsi Tentang Sanksi } \\
\text { Perpajakan }(\mathrm{X} 4)\end{array}$ & 1,040 & 0,073 & 0,782 & 14,267 & 0,000 & 0,920 \\
\hline $\mathrm{R}$ & & & & & 0,992 & \\
\hline $\mathrm{R}^{2}$ & & & & & 0,983 & \\
\hline Adjusted $R^{2}$ & & & & & 0,982 & \\
\hline
\end{tabular}

Konstanta sebesar 0,933 menyatakan bahwa apabila variabel kesadaran wajib pajak, kualitas pelayanan, pengetahuan perpajakan, dan persepsi wajib pajak tentang sanksi perpajakan sama dengan nol maka kepatuhan wajib pajak meningkat sebesar 0,933 satuan.

Nilai koefisien $B_{1}=0,094$ menunjukkan bahwa terdapat pengaruh positif dan signifikan antara variabel kesadaran wajib pajak $\left(\mathrm{X}_{1}\right)$ terhadap variabel kepatuhan wajib pajak reklame (Y) sebesar 0,094. Hal ini berarti apabila variabel kesadaran wajib pajak $\left(\mathrm{X}_{1}\right)$ naik sebesar 1 satuan dengan asumsi bahwa variabel 
bebas lainnya konstan, maka variabel kepatuhan wajib pajak reklame (Y) diharapkan meningkat 0,094 satuan.

Nilai koefisien $B_{2}=0,067$ menunjukkan bahwa terdapat pengaruh positif dan signifikan antara variabel kualitas pelayanan $\left(\mathrm{X}_{2}\right)$ terhadap variabel kepatuhan wajib pajak reklame (Y) sebesar 0,067. Hal ini berarti apabila variabel kualitas pelayanan $\left(\mathrm{X}_{2}\right)$ naik sebesar 1 satuan dengan asumsi bahwa variabel bebas lainnya konstan, maka variabel kepatuhan wajib pajak reklame (Y) diharapkan meningkat 0,067 satuan.

Nilai koefisien $\mathrm{B}_{3}=0,165$ menunjukkan bahwa terdapat pengaruh positif dan signifikan antara variabel pengetahuan perpajakan $\left(\mathrm{X}_{3}\right)$ terhadap kepatuhan wajib pajak reklame (Y) sebesar 0,165. Hal ini berarti apabila variabel pengetahuan perpajakan $\left(\mathrm{X}_{3}\right)$ naik sebesar 1 satuan dengan asumsi bahwa variabel bebas lainnya konstan, maka variabel kepatuhan wajib pajak reklame (Y) diharapkan meningkat 0,165 satuan.

Nilai koefisien $\mathrm{B}_{4}=0,782$ menunjukkan bahwa terdapat pengaruh positif dan signifikan antara variabel persepsi wajib pajak tentang sanksi perpajakan $\left(\mathrm{X}_{4}\right)$ terhadap kepatuhan wajib pajak reklame (Y) sebesar 0,782. Hal ini berarti apabila variabel persepsi wajib pajak tentang sanksi perpajakan $\left(\mathrm{X}_{4}\right)$ naik sebesar 1 satuan dengan asumsi bahwa variabel bebas lainnya konstan, maka variabel kepatuhan wajib pajak reklame (Y) diharapkan meningkat 0,782 satuan.

Berdasarkan Tabel 8 dapat dilihat bahwa hasil uji $\mathrm{F}$ menunjukkan nilai $F_{\text {hitung }}$ sebesar 727,186 dengan nilai signifikansi sebesar 0,000. Nilai signifikan tersebut lebih kecil dari pada 0,005, sehingga disimpulkan bahwa kesadaran wajib 
pajak, kualitas pelayanan, pengetahuan perpajakan, dan persepsi tentang sanksi perpajakan berpengaruh pada kepatuhan wajib pajak reklame dan variabel independen layak digunakan untuk memprediksi variabel dependen sehingga pembuktian hipotesis dapat dilakukan.

\section{Tabel 8}

Hasil Kelayakan Model (Uji F)

\begin{tabular}{lccccc}
\hline \multicolumn{1}{c}{ Model } & Sum of & df & Mean Square & F & Sig. \\
& Squares & & & & \\
\hline 1 Regression & 164,871 & 4 & 41,218 & 727,186 & 0,000 \\
Residual & 2,777 & 49 & 0,057 & & \\
Total & 167,648 & 53 & & & \\
\hline Sumber $:$ Data diolah, 2019 & & &
\end{tabular}

Nilai $\mathrm{P}_{\text {-value }} 0,016<\alpha=0,05$ sehingga $\mathrm{H}_{1}$ diterima yang bererti bahwa kesadaran wajib pajak berpengaruh signifikan pada kepatuhan wajib pajak reklame. Nilai $\mathrm{P}_{\text {-value }} 0,003<\alpha=0,05$ sehingga $\mathrm{H}_{2}$ diterima yang berarti bahwa kualitas pelayanan berpengaruh signifikan pada kepatuhan wajib pajak reklame. Nilai $\mathrm{P}_{\text {-value }} 0,005<\alpha=0,05$ sehingga $\mathrm{H}_{3}$ diterima yang berarti bahwa pengetahuan perpajakan berpengaruh signifikan pada kepatuhan wajib pajak reklame.Nilai $\mathrm{P}_{\text {-value }} 0,000<\alpha=0,05$ sehingga $\mathrm{H}_{4}$ diterima yang berarti bahwa persepsi wajib pajak tentang sanksi perpajakan berpengaruh signifikan pada kepatuhan wajib pajak reklame.

Tabel 7 memperlihatkan bahwa koefisien determinasi $\left(\mathrm{R}^{2}\right)$ memiliki nilai sebesar 0,983 yang berarti 98,3 persen variasi kepatuhan wajib pajak reklame dipengaruhi oleh variasi kesadaran wajib pajak, kualitas pelayanan, pengetahuan perpajakan, dan persepsi wajib pajak tentang sanksi perpajakan, sedangkan 
sisanya 1,7 persen dipengaruhi oleh faktor lainnya yang tidak dimasukkan dalam penelitian ini.

Nilai $\beta_{1}=0,155$ dengan tingkat signifikansi uji t uji satu sisi sebesar 0,016 menunjukkan angka lebih kecil dari pada taraf nyata dalam penelitian ini yaitu 0,05. Hal ini mengindikasikan bahwa perubahan yang terjadi pada variabel kesadaran wajib pajak akan berpengaruh signifikan terhadap kepatuhan wajib pajak. Hasil penelitian menunjukkan nilai koefisien regresi sebesar 2,505 yang menunjukkan bahwa variabel kesadaran wajib pajak memiliki pengaruh positif terhadap terhadap kepatuhan wajib pajak. Hasil penelitian mendukung hipotesis $\mathrm{H}_{1}$ yakni kesadaran wajib pajak berpengaruh positif terhadap kepatuhan wajib pajak reklame.

Hasil penelitian ini mendukung hasil penelitian sebelumnya yang dilakukan oleh Mahfud (2017) dan Putra (2018) dimana hasil penelitiannya menyimpulkan bahwa rasio kesadaran wajib pajak berpengaruh positif dan signifikan terhadap kepatuhan wajib pajak. Pengetahuan dan pemahaman tentang perpajakan sangat penting karena dapat membatu wajib pajak dalam mematuhi aturan perpajakan. Pemahaman tentang pajak serta kesungguhan wajib pajak untuk melaporkan dan membayar kewajiban perpajakannya dapat mencerminkan tingkat kesadaran wajib pajak. Apabila wajib pajak mengetahui dan paham tentang perpajakan maka kesadaran wajib pajak akan semakin tinggi yang berarti bahwa dapat meningkatkan kepatuhan wajib pajak untuk memenuhi kewajiban perpajakannya.

Nilai $\beta_{2}=0,027$ dengan tingkat signifikansi uji t satu sisi sebesar 0,003 menunjukkan angka lebih kecil dari pada taraf nyata dalam penelitian ini yaitu 
0,05. Hal ini mengindikasi bahwa perubahan yang terjadi pada variabel kualiatas pelayanan akan berpengaruh signifikan terhadap kepatuhan wajib pajak. Hasil penelitian menunjukkan nilai koefisien regresi sebesar 3,101 yang menunjukkan bahwa variabel kualitas pelayanan memiliki pengaruh positif terhadap kepatuhan wajib pajak. Hasil penelitian ini mendukung hipotesis $\mathrm{H}_{2}$ yakni kualitas pelayanan berpengaruh positif terhadap kepatuhan wajib pajak reklame.

Hasil penelitian ini mendukung hasil penelitian sebelumnya yang dilakukan oleh Pratiwi \& Setiawan (2014) yang menunjukkan bahwa kualitas pelayanan berpengaruh positif dan signifikan terhadap kepatuhan wajib pajak reklame. Kualitas pelayanan dapat menjadi tolak ukur masyarakat mengenai pelayanan yang diberikan, apakah masyarakat puas atau tidak puas dengan layanan yang diberikan. Wajib pajak akan cenderung patuh dalam memenuhi kewajiban perpajakannya tergantung bagaimana petugas pajak memberikan mutu pelayanan terbaik kepada wajib pajaknya. Kualitas pelayanan tidak hanya terlihat dari sikap petugas pajak kepada wajib pajaknya, namun memberikan informasi secara langsung pada wajib pajak sebelum melakukan suatu perubahan prosedur, baik tata cara pembayaran maupun perubahan tarif pajak juga merupakan bentuk pelayanan yang baik. Dengan memberikan pelayanan yang cepat dan informasi yang jelas kepada wajib pajak akan membuat wajib pajak nyaman dalam membayar pajak dan dapat meningkatkan kepatuhannya dalam membayar pajak.

Nilai $\beta_{3}=0,207$ dengan tingkat signifikansi t uji satu sisi sebesar 0,005 menunjukkan angka lebih kecil dari pada tarif nyata dalam penelitian ini yaitu 0,05. Hal ini mengidentifikasikan bahwa perubahan yang terjadi pada variabel 
pengetahuan perpajakan akan berpengaruh signifikan terhadap kepatuhan wajib pajak. Hasil penelitian menunjukkan nilai koefisien regresi sebesar 2,941 yang menunjukkan bahwa variabel pengetahuan perpajakan memiliki pengaruh positif terhadap kepatuhan wajib pajak. Hasil penelitian ini mendukung hipotesis $\mathrm{H}_{3}$ yakni pengetahuan perpajakan berpengaruh positif terhadap kepatuhan wajib pajak reklame.

Hasil penelitian ini mendukung hasil penelitian sebelumnya yang dilakukan oleh Sucandra \& Supadmi (2016) dimana menunjukkan bahwa variabel pengetahuan perpajakan berpengaruh positif dan signifikan pada kepatuhan wajib pajak restoran. Pengetahuan perpajakan merupakan hal penting dalam membantu wajib pajak dalam melaksanakan kewajibannya khususnya pengetahuan dasar tentang perpajakan. Tanpa mempunyai pengetahuan mengenai perpajakan, manfaat dari membayar pajak, dan fungsi pajak maka tidak satupun wajib pajak akan dengan iklas membayar pajaknya. Apabila wajib pajak mempunyai pengetahuan perpajakan yang cukup maka dapat meningkatkan kepatuhan wajib pajak untuk memenuhi kewajiban perpajakannya.

Nilai $\beta_{4}=1,040$ dengan tingkat signifikansi uji t satu sisi sebesar 0,000 menunjukkan angka lebih kecil daripada taraf nyata dalam penelitian ini yaitu 0,05. Hal ini mengindikasikan bahwa perubahan yang terjadi pada variabel persepsi wajib pajak tetang sanksi perpajakan akan berpengaruh signifikan terhadap kepatuhan wajib pajak. Hasil penelitian menunjukkan nilai koefisien regresi sebesar 14,267 yang menunjukkan bahwa variabel persepsi wajib pajak tentang sanksi perpajakan memiliki pengaruh positif terhadap kepatuhan wajib 
pajak. Hasil ini membuktikan hipotesis $\mathrm{H}_{4}$ yakni persepsi wajib pajak tentang sanksi perpajakan berpengaruh postif terhadap kepatuhan wajib pajak reklame.

Hasil penelitian mendukung penelitian sebelumnya yang dilakukan oleh Wardani (2018) dan Nelsi (2017) menyatakan bahwa persepsi sanksi pajak berpengaruh terhadap kepatuhan wajib pajak. Penerapan sanksi perpajakan kepada wajib pajak dimaksud agar wajib pajak tidak lalai dengan kewajibannya dan menaati peraturan perpajakan. Wajib pajak akan memenuhi kewajiaban perpajakannya apabila melihat bahwa sanksi perpajakan akan lebih banyak merugikannya sehingga wajib pajak akan berpikir untuk menghindari sanksi perpajakan dengan membayar tepat waktu atau membayar tidak melewati jangka waktu yang telah ditetapkan, sehingga dengan adanya sanksi perpajakan akan mendorong wajib pajak untuk patuh pada kewajiban perpajakkannya.

\section{SIMPULAN}

Berdasarkan analisis data pada bab sebelumnya maka dapat diambil kesimpulan bahwa pengaruh kesadaran wajib pajak, kualitas pelayanan, pengetahuan perpajakan, dan persepsi wajib pajak tentang sanksi perpajakan berpengaruh positif dan signifikan dengan koefisien determinasi sebesar 98,3\%. Kemampuan prediksi masing- masing variabel sebagai berikut

Pengaruh kesadaran wajib pajak terhadap kepatuhan wajib pajak reklame di Badan Pendapatan Daerah Kabupaten Badung sebesar 1\% positif dan signifikan pada alpha 5\%. Pengaruh kualitas pelayanan terhadap kepatuhan wajib pajak reklame di Badan Pendapatan Daerah Kabupaten Badung sebesar 
2,2\% positif dan signifikan pada alpha $5 \%$. Pengaruh pengetahuan perpajakan terhadap kepatuhan wajib pajak reklame di Badan Pendapatan Daerah Kabupaten Badung sebesar $4,8 \%$ positif dan signifikan pada alpha 5\%.Pengaruh persepsi wajib pajak tentang sanksi perpajakan terhadap kepatuhan wajib pajak reklame di Badan Pendapatan Daerah Kabupaten Badung sebesar $92 \%$ positif dan signifikan pada alpha $5 \%$.

Berdasarkan hasil penelitian serta hal-hal yang terkait dengan keterbatasan penelitian ini, maka dapat diberikan saran-saran sebagai berikut:

Badan Pendapatan Daerah Kabupaten Badung harusnya dapat menjaga dan meningkatkan kualitas pelayanan yang diberikan kepada wajib pajak khususnya wajib pajak reklame seperti meningkatkan infrastruktur fisik pendung kenyamanan wajib pajak. Kegiatan sosialisasi juga disarankan untuk dilakukan agar dapat menumbuhkan kesadaran wajib pajak dalam mematuhi kewajiban perpajakannya serta memberikan pengetahuan kepada wajib pajak tentang pelaksanaan pajak.

Penelitian ini juga terbatas hanya meneliti kepatuhan wajib pajak reklame di Badan Pendapatan Daerah Kabupaten Badung. Penelitian selanjutkan disarankan dapat menambah jumlah sampel dengan cara memperluas wilayah penelitian sehingga hasil penelitian dapat digeneralisasikan. Penambahan variabel-variabel lain yang dianggap dapat berpengaruh terhadap kepatuhan wajib pajak reklame juga diharapkan pada penelitian selanjutnya.

\section{REFERENSI}


Budhiartama, P. I. G., \& Jati, I. K. (2016). Pengaruh Sikap, Kesadaran Wajib Pajak dan Pengetahuan Perpajakan Pada Kepatuhan Membayar Pajak Bumi dan Bangunan. E-Jurnal Akuntansi Universitas Udayana, 15(2), 1510-1535.

Darmayanti, E. F., \& Rahayu, S. R. (2017). Sosialisasi Pajak Kepada Para Pedagang Untuk Meningkatkan Kesadaran, Kepercayaan, dan Kepatuhan Sebagai Wajib Pajak. Jurnal Pengabdian Universitas Muhammadiyah Metro, 1(1), 1-20.

Dewi, K. L. P. S., \& Merkusiwati, N. K. L. A. (2018). Pengaruh Kesadaran Wajib Pajak, Sanksi Perpajakan, E-Filing, dan Tax Amnesty Terhadap Kepatauhan Pelaporan Wajib Pajak. E-Jurnal Akuntansi Universitas Udayana, 22(2), $1626-1655$.

Fisher, C. M., Wartick, M., \& Mark, M. M. (1992). Detection Probability and Tax Payer Compliance: A Literature Review. Journal of Accounting Literature, 11(1), 1-46.

Gerald, C., \& Leung, P. (2009). A Critical Review of Fischer Tax Compliance Model (A Research Syntesis). Journal of Accounting and Taxation, 1(2), 3440.

James, S., \& Nobes, C. (1997). The Economics of Taxation, Priciple, Policy and Practise. Europe: Prentice Hall.

Jatmiko, A. . (2006). Pengaruh Sikap Wajib Pajak pada Pelaksanaan Sanksi Denda, Pelayanan Fiskus, dan Kesadaran Perpajakan Terhadap Kepatuhan Wajib Pajak Studi Empiris Terhadap Wajib Pajak Orang Pribadi di Kota Semarang. Universitas Diponegoro.

Jaya, M. I. B., \& Jati, I. K. (2016). Pengaruh Kesadaran, Kualitas Pelayanan, Pemeriksaan dan Sanksi Perpajakan Pada Kepatuhan Wajib Pajak Restoran. E-Jurnal Akuntansi Universitas Udayana, 16(1), 471-500.

Kusuma, A. I. B., \& Supadmi, N. L. (2016). Pengaruh Kesadaran, Kualitas Pelayanan, Sanksi dan Pemahaman Peraturan Perpajakan Pada Kepatuahan Wajib Pajak Hotel. E-Jurnal Akuntansi Universitas Udayana, 17(1), 565590.

Lisnawati. (2012). Pengaruh Pengetahuan Pajak dan Modernisasi Sistem Administrasi Kepatuhan Wajib Pajak Orang Pribadi. Bandung: Unikom.

Mahfud, M. A. dan S. A. (2017). Pengaruh Pemahaman Peraturan Perpajakan, Kesadaran Membayar Pajak dan Kualitas Pelayanan Perpajakan Terhadap Kepatuhan Wajib Pajak Badan (Studi Empiris Pada Koperasi di Kota Banda Aceh). Jurnal Megister Akuntansi Pascasarjana Universitas Syiah Kuala, 6(3), 1-18. 
Marziana, B. H. M., Norkhazimah, B. A., \& Sakarnor, M. B. D. (2010). The Reletionship Between Perceptions and level of compliance Under Self Assessment System-A Study in The East Coast Region. Journal of Global Business and Economic, 1(1), 241-257.

Munari. (2005). Pengaruh Faktor Tax Payer Terhadap Keberhasilan Penerimaan Pajak Penghasilan (Studi Kasus KPP Batu, Malang). Jurnal Eksekutif, 2(2), $120-134$.

Nelsi, A. (2017). Pengaruh Pemahaman Perpajakn Wajib Pajak, Kesadaran Wajib Pajak, dan Sanksi Pajak Terhadap Kepatuhan Wajib Pajak Orang Pribadi Yang Melakukan Kegiatan Bisnis Online di Pekanbaru. Jurnal Ilmiah Ekonomi Dan Bisnis, 1(1), 1-12.

Niemirowski, P., Wearing, A., Baldwin, S., Leonard, B., \& Mobbs, C. (2002). The influence of tax related behaviours, bellefs, attitudes and values on Australian taxpayer compliance. Is tax avoidance intentional and howserious an offence is it? University of New South Wales.

Noormala, S. O. (2008). Voluntary compliance; tax education preventiv. International Conference on Bussiness and Economy Constanta Romania. International Islamic University Malaysia.

Nugroho, A. (2012). Strategi Jitu: Memilih Metode Statistik Penelitian dengan SPSS. Yogyakarta: Andi Offset.

Palil, M. R. (2005). Does Tax Knowledge Matter in Self Assessment System? Evidence From Malaysia Tax Administrative. The Journal of American Academy of Business, 2(1), 3-8.

Pratiwi, I. G. A. M. A. M. A., \& Setiawan, P. E. (2014). Pengaruh Kesadaran Wajib Pajak, Kualitas Pelayanan, Kondisi Keuangan Perusahaan, Dan Persepsi Tentang Sanksi Perpajakan Pada Kepatuhan Wajib Pajak Reklame di Dinas Pendapatan Kota Denpasar. E-Jurnal Akuntansi Universitas Udayana, 1(2), 456-473.

Putra, A. P. (2018). Pengaruh Kesadaran Wajib Pajak, Kualitas Pelayanan, Serta Persepsi Tentang Denda Pada Kepatuhan Wajib Pajak Reklame di Dinas Pendapatan Kota Surabaya. Jurnal Akuntansi UNESA, 6(2), 1-20.

Razak, A. A., \& Adafula, C. J. (2013). Evaluating taxpayers, attitude and its influence on tax compliance decisions in Temale Ghana. Journal of Accounting Abd Taxation, 5(3), 1-20.

Sucandra, P. L. K. I., \& Supadmi, N. L. (2016). Pengaruh Kualitas Pelayanan, 
Ni Putu Mirah Sri Devi Permatasari dan Ni Ketut Lely Aryani M. Pengaruh ...

Pemeriksaan Pajak, Pengetahuan Perpajakan dan Sanksi Perpajakan Pada Kepatuhan Wajib Pajak Restoran. E-Jurnal Akuntansi Universitas Udayana, 16(2), 1210-1237.

Tiraada, T. A. . (2013). Kesadaran Perpajakan, Sanksi Pajak, Sikap Fiskus Terhadap Kepatuhan WPOP di Kabupaten Minahasa Selatan. Jurnal EMBA, 1(3), 999-1008.

Wardani, R. T. (2018). Pengaruh Persepsi Wajib Pajak, Kualitas Pelayanan Fiskus, Pemahaman Perpajakan, dan Kemanfaatan NPWP Terhadap Kepatuhan Wajib Pajak. STIE Perbanas Surabaya.

Wirawan, I. B., \& Burton, R. (2013). Hukum Pajak. Jakarta: Salemba Empat.

Zain, M. (2008). Manajemen Perpajakan. Jakarta: Salemba Empat. 